\title{
Childhood Ideology in the Early Turkish Republican Era
}

\author{
Filiz Yıldız ${ }^{1} \&$ Özlem Aydoğmuş Ördem ${ }^{1}$ \\ ${ }^{1}$ Communication Faculty, Cukurova University, Adana, Turkey \\ Correspondence: Filiz Yıldı, Communication Faculty, Cukurova University, Adana, Turkey. E-mail: \\ oaydogmus@cu.edu.tr
}

Received: March 7, 2018

doi:10.5539/jpl.v11n3p82
Accepted: March 25, $2018 \quad$ Online Published: August 30, 2018

URL: https://doi.org/10.5539/jpl.v11n3p82

\begin{abstract}
Studies on ideology in the social sciences have been incremental in recent decades. Childhood ideology remains a pivotal issue in the humanities from pedagogy to philosophy. Since children are easily accessible ideological subjects, the exercise of ideology can be more clearly noticed in children. This study aims to focus on childhood ideology adopted by the authorities in the early Turkish Republican Era. The emergence and rise of nationalism from 1923 directed by the authorities to focus on what kind of generation they would raise for the future of the Turkish Republic. The study involved four regularly published newspapers-Cumhuriyet, Akşam, Vakit/Kurun, Hakimiyet-i Milliye/Ulus- dating back to 1930s. The main goals of the modernization project of the Republic were raising honest, industrious, patriotic and healthy children, which were the main individuals that had to be reared for the new Republic. Thus, a strong relationship between Turkish nationalism and the new types of children was established.
\end{abstract}

Keywords: children, early Turkish Republican Era, ideology, robust children ideology

\section{Introduction}

Ideology has always been a central concept in social sciences in the last two hundred years. Therefore, various definitions have been put forward (Alexander, 2004: Zizek, 1989). However, this study adopts the definition attested by Alexander (2004) who defines ideology as 'a view about what ought to be thought, said and done about politics in terms of a sole criterion, where that sole criterion is a suggestion about to what or whom a fundamental debt is owed; and where this view is contested by views dependent on rival criteria within a situation which is constituted by the continual contestation of criteria (p.4).' Each society or group interprets and transforms ideology in different ways. However, it is clear that ideology imposes a set of ideas, beliefs, attitudes, behaviors or lifestyles on individuals. Childhood ideology in the Early Turkish Republican Era also dictates some certain principles in accordance with the ideas of the newly established Republic of Turkey. These ideas entail raising robust, healthy and nationalistic children that exist only for the state. Thus, children were raised based on national principles, values and ideas of the Early Turkish Republic. A good citizen referred to those who could serve their state within the parameters of nationalism and discipline. This new generation was to be raised as guarantors of the new Republic that needed to be constantly protected. Thus, in line with the definition attested by Alexander (2004), curricula and syllabi in schools that told children what to be done, thought and followed were strictly prepared. Being a Turk and learning Turkish language, history of Turkish peoples, values of the new Turkish Republic were strictly taught and reinforced. It is true that children were seen as independent young individuals. However, these young individuals were not autonomous or independent of the principles of the new state. How they would be raised was based on the values and impositions of the nationalistic state. Thus, it can be said that the identity of children in the Early Turkish Republic was historically recognized but was totally dependent on the fundamental principles, parameters and values of the new state. The origins of this historically recognized idea first emerged in the $19^{\text {th }}$ century in Ottoman Empire influenced by the French Revolution and the westerns schools that were opened by foreigners in the Empire.

Beginning from the second half of the nineteenth century, the consideration of the child as an independent individual has been accepted under the influence of westernization because western-based schools were opened in Ottoman Empire that had to change its educational curricula and had to open new schools in accordance with western schools. Still, religion-based education was dominant but schools from elementary to high schools for girls were opened. Another outstanding aspect of this framework is the close relationship between the motherland and the family. Loving parents and siblings has been identified as the first step in loyalty and devotion to society 
(Onur, 2005).

If children love their family, this spiritual feeling can also be given within the frame of homeland love. The homeland has been given to children like the mother, the father and the sister who need to be loved. The presentation of the Sultan as the father of the country in the constitutional monarchy has a different meaning in this context. The image of the sultan who protects, observes and caresses with compassion is almost proof that the absolute monarchy is compared to the ideal family leader (Onur, 2005 \& Öztan, 2009). The process that started with the proclamation of the second Constitutionalism reformed the ideal child concept to a large extent based on citizenship. Üstel (2005) notes that the child who started to become an independent subject with Tanzimat between 1838 and 1876. As the future of the Ottoman society as a future, the child \& future citizen has been positioned and assigned as an entrepreneur and a soldier, not just of his family, but of the whole society - and of course the state. This new state was based on direct monarchy imposed by the Sultan of Abdülhamit who wanted Islam to be dominant across the country (Üstel, 2005).

The ideal definition of childhood in this frame is reconstructed under the influence of the nationalist jargon, just as it is for adults. The establishment of a new national pedagogue was considered essential for the nation's future and national prestige, and the revitalization of the national spirit in children was declared as a primary goal (Öztan, 2009). In children's books and magazines published after 1913, the emphasis of Turkish culture and language is blended with foreign fears and worries, and it is suited to the promised goal. The nationalist ideologues Ziya Gokalp, Aka Gündüz, Hüseyin Ragıp and Mehmet Emin were the main propagandists in the Children's World, while Yusuf Akçura promoted nationalist propaganda in children's books. The traumatic effect of the lands lost in the Balkan Wars has fueled the whimpering and militarist debate about revenge and violence. The children were envisaged as future soldiers who will take revenge for the land that will be lost in the future, and will return blood (Öztan, 2009 \& Üstel, 2005).

After the proclamation of the Republic, the basic political project of the ideologues of the new regime is to train new generations who have a constituent / guardian Kemalist image attached to the values and revolutions of the republic (Öztan, 2009). At the same time, a republican generation that has accepted the inside of its national borders as paradise is the assurance of the future. All reforms undertaken in the field of education and training are designed to achieve the ideal of modernization and development promised by the new regime by creating republican generations (Okay, 1998).

In almost all the texts of the stories regarding children, it has been argued that the republic has been in many ways, that it has made a historic beginning for the children, and that this beginning also guarantors the future. Since the emergence of the modern childhood paradigm in the Ottoman territories, righteousness, honesty, orderliness and diligence have been at the forefront of the basic characteristics attributed to the ideal child (Şirin, 2013). Accuracy and diligence are kept on the agenda of children's publications by using different parameters at different periods. Sometimes, in the context of patriarchal loyalty, sometimes fear of God, sometimes in the context of citizenship or Turkishness, the invariable features of children are mentioned in detail (Üstel, 2005). Especially after 1908, the main factor that multiplied the eye is the proliferation of texts expressing that children are expected to be correct, honest, sophisticated and hardworking for their homeland and nation (Şirin, 2013). In the Republican era, always saying and constantly working for the prerogative and welfare of the Turkish nation and the home have been processed directly or indirectly in both textbooks and popular publications as an indispensable feature of the ideal child. It can be said that ideologically mothers were assigned more responsibilities, and expectations from fathers were secondary.

The child is the most important element of the population politics (Okay, 1998 \& Şirin, 2013), as well as being a symbol of desire for modernization and a Political Collaboration of the republic for the new regime. The birth of the children was placed at the center of national politics and thus the census became a central issue. So, according to the republic's elites, the multiplicity of children is a confirmation of the existence of nationality.

Health and population work are almost entirely focused on the growth of healthy children. Therefore, it is not possible to deny the prospect of the population increase in the republic's modernization prospect and the head of child care within the child's case. Especially in the 1930s, along with the pro-natalist population policies of racial reform projects, traces of ethnicalist approaches to child and health relations became evident in publications both for adults and for children. It should be stated that this framework is applied as a center of a two-way effort. First, it is aimed to strengthen children's physical and mental characteristics. It is desired to rationalize the current power in the light of current health information while systemizing the basic needs and reestablishing the power over the child's body (Üstel, 2005 \& Şirin, 2013). Every headline, from feeding to sleeping hours, from clothing to gymnastics, is dedicated to the idea of how children will be healthier and more robust for the nation's future 
(Şirin, 1999). In order to keep children away from illnesses (especially from infectious ones) and from bad habits (alcohol, tobacco products, etc.) there has been an intensive informing process by which a relatively wide range of school health publications and textbooks were prepared for parents, teachers and tutors (Oztan, 2009). Therefore, any obstacle that would cause diseases had to be ridded because the new generation had to be robust and healthy individuals that would serve the state. In addition, the thesis that weak, diseased and addicts constitute obstacles to national development has been repeated (Öztan, 2009).

For this reason, while the project of civilization in the early Republican period is almost entirely indexed to the West, the insistence that the methods of conceptualizing childhood should be arranged according to the national principle should not be overlooked (Balibar, 2002). It should be stated that the modernized state has delayed the construction of the form, investigator, questioning individual who has emphasized the obedience and rigorous discipline of regime conservation efforts and adopted a didactic style (Okay, 1998 \& Șirin, 1999 \& Üstel, 2005 \& Şirin, 2013). The construction of childhood, which is so connected to the leader's culture and is based on the idea and conscience of public responsibility, national interests, daily life, national rituals and the intertwined relations with it, has greatly delayed the formation of a sub-structure to absorb civil-democratic values. It is obvious that the ideal child, given the modernization project, is not the only form available today, when an assessment that includes recent history is made. If we go a step further, it can be argued that the dominant discourse described throughout the study is not internalized to all segments. But the fact that such an internalization does not happen with all its elements has not reduced the power of mobilization to the dominant one. In other words, individuals have participated in collective sanctification and certain political rituals through various social control mechanisms in situations where there is no internalization in collectivity (Ageci, 2007). In addition, it can be interpreted as explicit or implicit consent as well as all compulsory elements. In addition, alternative childhood constructs that have emerged from the existing cultural codes and political methodology have not progressed greatly to the same grammatical derivation. It can be argued that alternative ideal of childhood forces children to go beyond the nationalist-developmental and militarist framework in many respects, especially in relation to their authority (Öztan, 2009).

Republican leaders and intellectuals were dealing with child education in the context of a new national identity that they were trying to create before anything else. The necessity of building a new nation for the created state forced the republican rulers to establish themselves as a homo nationalis, but also as homo economicus, homo politicus and homo religious with a network of everyday practices and apparatuses from birth to death of the individual (Balibar, 2007: 115). In order to build the ideal citizen of the Republic, he was interested in the child affairs as well as in both biological and political construction. Indeed, these two aspects were two important and co-existing stages in the context of child education. New national definitions, their adoption and internalization were the goal of the child's political construction. The child is the first and foremost stop in creating a homogeneous society.

\subsection{Research Questions}

1) How are the children depicted in early Turkish Republican newspapers?

2) What ideology is emphasized in these newspapers?

3) Is there consistency in that the newspapers handle the new generation at descriptive level?

\section{Method}

The study was descriptive and qualitative in nature. There are two main approaches, inductive and deductive, to examine data in social sciences. The inductive approach aims to analyze specific data with possible categories whose definitions are hardly operationalized (Brannen, 2017; Bryman, 2004; Creswell \& Miller, 2000; Creswell \& Poth, 2017). It is often composed of limited number of data that may not be replicated at cross-national level. In this study, an inductive content analysis was carried out to elicit the categories because inductive analysis entails extraction of topics, themes and categories from the data (Brannen, 2017; Bryman, 2004; Creswell \& Miller, 2000; Creswell \& Poth, 2017; Schilling, 2006; Tashakkori \& Teddlie, 2003).

\subsection{Procedure}

Within the scope of this study, the articles from Akşam, Cumhuriyet, Hakimiyet-i Milliye/Ulus and Vakit/Kurun were examined by analyzing the documents dated between January 01, 1930 and December 31, 1938. During the period, while ten different newspapers published, those four were explicitly chosen since they were published on a regular basis from 1930 to 1938 . The relevant copies have been obtained from the National Library of the Periodical Publications archive microfilm unit.

Hâkimiyet-i Milliye, one of the leading newspapers of the National Struggle years, which was also the advocate of the official ideology in the single party period. The founding capital of the paper was belong to Mustafa 
Kemal and started its publication life on January 10, 1920. On November 28, 1934, it was published under the title Ulus. Among the editorial writers were Hüseyin Ragıp, Ağaoğlu Ahmet, Ruşen Eşref Ünaydın, Mahmut Esat Bozkurt, Mahmut Soydan, Zeki Mesut and Falih Rifkı Atay. In the 1930s, the Hakimiyet-i Milliye / Ulus was frequently published in 8 pages and in irregular 12 pages.

Founded by Ahmet Emin Yalman and Asım Us, Vakit Newspaper began its publication life on October 22, 1917. One of the important developments in the history of Vakit was that Mustafa Kemal Atatürk wrote the editorials of the journal for five days between 22 and 26 January 1937. Vakit is usually published in 10 or 12 pages, sometimes up to in 8 pages. His authors were Asım Us, Sadri Etem, Hikmet Münir and Yusuf Ziya. The newspaper continued to be published under the name Kurun after November 22, 1934, when Turkish language studies were emphasized. The new name of the journal was given by Atatürk as a result of the efforts of using the Turkish names in every field of life.

Cumhuriyet newspaper was founded by Yunus Nadi, Zekeriya Sertel and Nebizade Hamdi Bey on May 7, 1924. Mustafa Kemal's requests from journalists who started publishing life at Cumhuriyet was to tell about the new regime, and to collect and to adopt its values. Yunus Nadi wrote mostly the editorials in the first column of the newspaper. According to the agenda, however, authors such as Abidin Daver, Aka Gündüz and Peyami Safa have been kept as editorials. There were names such as Ziya Gökalp, Aka Gunduz, Ahmet Rasim, Peyami Safa, Abidin Daver, Burhan Belge, Yavuz Abadan, Nurullah Ataç, Cevat Fehmi Başkut and Halit Ziya Uşaklıgil in the writings of the writers. The publication policy of Cumhuriyet in the 1930s, which is examined in the study, was a direct defense of the official ideology. Newspapers were often printed in 8 pages, but some days they appeared in 12 pages.

Akşam was founded by Necmettin Sadak, Kazim Sinai Dersan, Falih Rifkı Atay and Ali Naci Karacan. The newspaper, which started its publication life on September 20, 1918, supported the resistance in Anatolia during the years of National Struggle. Enis Tahsin Til was in charge of the editorial office of the journal. Necmettin Sadak was, also, the editor for many years. Among the authors of the journal were Vâlâ Nurettin (Vâ-Nû), Hikmet Feridun Es, and Selami Izzet Sedes. The newspaper was mostly published in 8 pages.

The issues of the Hakimiyet-i Milliye/Ulus, Vakit/Kurun, Akşam and Cumhuriyet journals were examined by the document analysis method to find contents about children. A total of 191 contents have been reached with, especially, expressing responsibility for mothers. 6 of these contents are categorized as advertisement text, 38 as news, 14 as cartoon and 133 as corner writing/article.

News related to the controversy are related to topics that are included in the routine news category and include planned activities such as various ceremonies, meetings, legal regulations, practices, and visits. As can be seen from the images, the news that was published in the photographs usually appeared on the first pages of the newspapers.

Advertisements that reflect the ideal of healthy and well-educated children were of Hasan Force Ball, Çapamarka children's food, Arsenoferratose appetizer syrup, Farinal children's food, Hasan Ozluns and Pertev Children's Powder products. The advertising texts promise to grow healthy, strong, and happy children, while the responsibility of ensuring these conditions was placed on the mothers. On the other hand, the mother would be happy if the products were used. Advertisement texts are consist of 12-112 words and contain visuals/drawings.

In the scope of the study, there are numerous columns on the Hakimiyet-i Milliye/Ulus, Akşam, Vakit/Kurun and Cumhuriyet newspapers and it is seen that the texts bear recommendations for mothers. The contents in this direction, which are sometimes taken by editorials, are on average 150-350 words (Note 1).

\subsection{Results}

The basic concepts that have emerged in the scope of this study are considered as the frequency of these concepts being included in the content which is classified as child care, child health, robust child/robustness, parent/mother, mother, parent, and father. The frequency of use of these concepts in texts is as follows: 
Table 1. Distribution of words regarding children

\begin{tabular}{cc}
\hline Words & N \\
\hline Mother/Maternity & 87 \\
Son/Baby & 64 \\
Robust children (Note 2) & 62 \\
Children's health & 59 \\
Raising children & 43 \\
Father (Note 3) & 23 \\
Mothers' lap (Note 4) & 13 \\
Parents & 8 \\
\hline
\end{tabular}

\section{Discussion}

National policy implementation of a healthy young generation took an important place in Early Republic Era (Note 5) because of deprecating life conditions, fatal epidemics such as tuberculosis, typhoid and cholera, and exclusively losing the most of the young male generation during the decade starting with Balkan War until the end of the Turkish National Struggle for Independence. According to Tekeli, population of Anatolia declined from 17.5 million to 12 million, corresponding to 30 percent (Tekeli, 1990: 59). After the establishment of the Turkish Republic, nationalist policies focused on educational activities to raise awareness of the public about bringing up a healthy future generation and decent individuals, and also the press disseminated messages on this course. In discourses of Mustafa Kemal Atatürk, the population problem and bringing up a healthy generation were emphasized and solving health problems, increasing the population and decreasing death rate were specified as paramount (Oktay, 2013: 36).

The main goals of the modernization project of the Republic were raising honest, industrious, patriotic and healthy children. Founding Fathers focused on the health policies for child welfare since they believed that a healthy, talented and republic-devoted generation was a guarantee of the newly funded regime. In order to achieve the duty of a raising healthy generation, the Republic struggled against fatal epidemics around the country, established pediatric services, provided medical supply to women during pregnancy and postpartum period, endeavored to minimize infant and child death rate which amount to 80 percent in some regions (Sarıkaya, 2012:203). The health and education organization of the young republic such as Kizllay (The Red Crescent), Himaye-i Etfal (Note 6) were mobilized to reach those goals. Summer camps, one of the activities for the defined goals, had very important places. Arranged by the Department of Education, the governorate, and Kızılay in 1930s, the Summer Camp accepted poor and care-seeking children with the motto of "Clear air, abundant food". Those children were fed well, and made sports in clear air (Duman, 2016;2211). In this period, to constitute social awareness, while some implementations were highlighted, women were defined as having maternity roles and given the responsibility of rising healthy children.

In designing the new society of the Republic, maidens who married and settled down when it was time were idealized as conscious mothers. In this era getting married and being a young mother was offered as the best choice. Pro-modernization discourse both accentuated women active in public sphere and also highlighted the biological function of women to produce a young and healthy generation.

It is significant that Mustafa Kemal Ataturk put emphasis on the maternity as the most sacred role, although he aimed to style successful and capable Turkish women in every aspect of public sphere. The discourse of Ataturk saying, "The main duty of the women is maternity" hung on the walls of maternity wards was an indication of that attitude. Among the main goals of the regime was to design Turkish women who organized domesticity, raised healthy children, had responsibility towards their husbands, were well versed about home economy, and who were frugal, rational and virtuous. This mentality, which is consonant with nationalist modernization projects, waited for women to raise patriot, diligent, respectful and healthy children (Toprak, 2015: 372; Kandiyoti, 2013: 233).

In the modernization period, another perspective about new women was to correlate illiterate women with an underdeveloped society. According to this opinion, if the mothers stayed illiterate, the kids would be illiterate. With the motto, "If the women are educated, well-educated generations can be raised", the women were given an important role within the family. According to Durna, the women, within the nation/family design of the 
Kemalist ideology, needed to use their domestic skills for wealth and prosperity of the nation, which is described as the family metaphor. The key concept about the women emerged as 'task sharing' instead of equality with the men in public sphere. Among those tasks were: raising children, looking after family members, being good at cooking, cleaning, setting the table, and lounging pleasurably their homes. Some women-only schools and night training vocational schools taught those tasks in order to make the women efficient at home (Durna, 2009:17).

Sancar, classifying the main task given ideologically to women during founding the nation as the "mother of the nation', pointed out "In nationalistic perspective, as a mother, the role of raising dutiful children under the educational opportunities bestowed to women. The maternity role took precedence over legitimizing the claiming rights. According to a gender perspective, shaped by nationalist ideology, the woman, first of all is a mother rather than an individual" (Sancar, 2013: 22, 55, 65). To realize this ideal, educational activities appeared in public sphere by the help of community centers, adult schools, formal education schools and non-governmental organizations. Turkish press of the era outshined as an ideological tool by putting policy of the healthy and robust children into circulation

Mass media is an influential tool on social change. It is also believed that the Turkish Press performed an important role in the modernization project in Early Republic Era. Founding Fathers regarded the press as an important tool to relate, impose and consolidate the revolutions and reforms to the public. It has been considered that the press introduced the expectations, the desired aspects and the changes about the idealized Turkish children within the framework of new regime's modernization perspective.

The Turkish Press in this era presented the women with gendered roles at home. In some expressions shown on the newspapers, it was highlighted that the principal role of women was maternity. Weekly woman pages on the press undertook the mission to produce 'new woman'. For example, Cumhuriyet, while designing these weekly women pages in the framework of the domestic and maternity roles of women, included fashion, beauty and etiquette. Furthermore, on these pages were columns on mothers and kids on a regular basis. On these columns, there appeared the didactic articles on child welfare, effective child communication with the others, and childcare. 


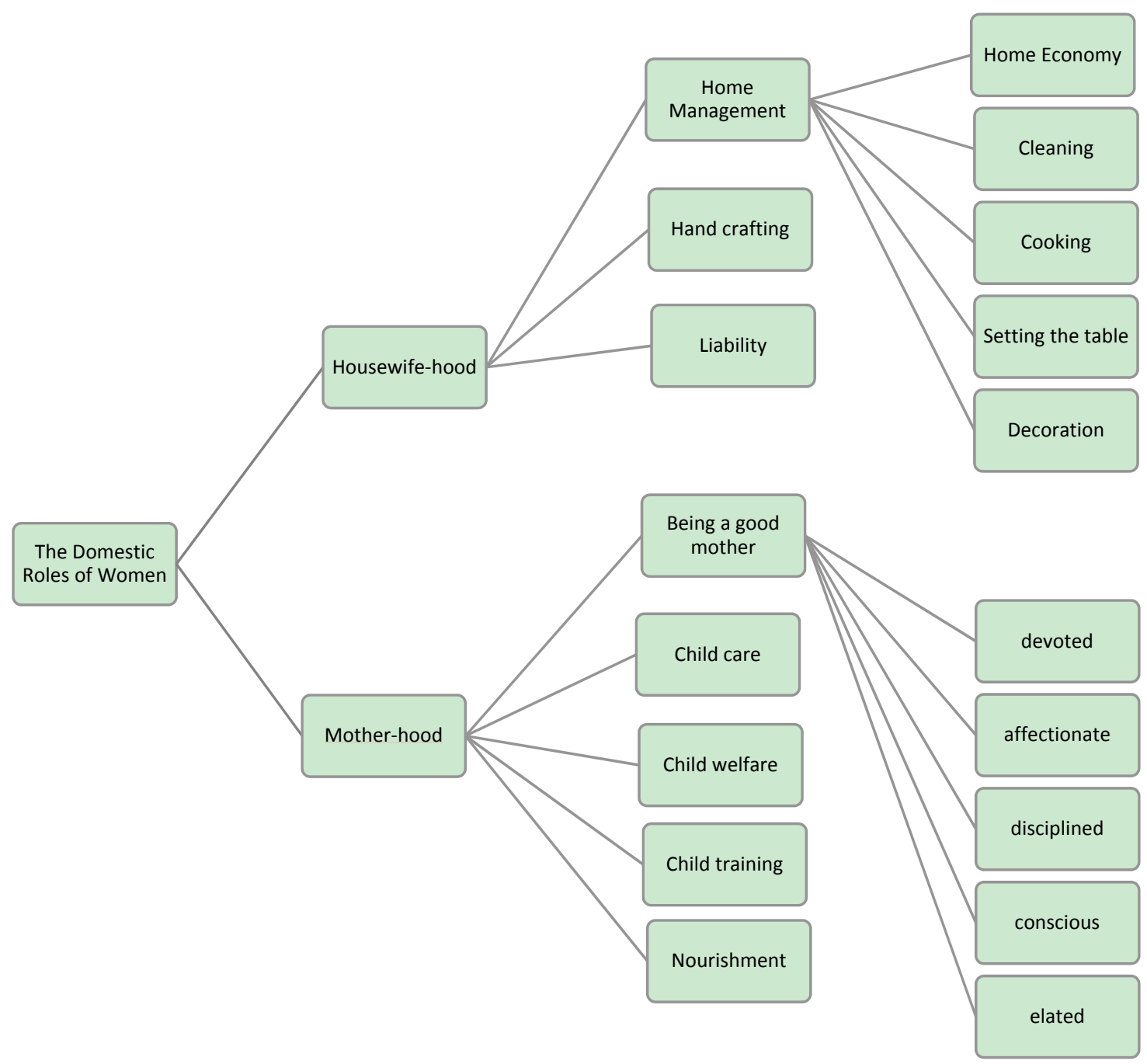

Figure 1. The women domestic roles terms used in the studied newspapers

Marriage institution, settling down, having children and raising a healthy and patriotic generation were all attitudes induced by the new regime and the press. An article on the "Home-Woman-Fashion" page of Akşam newspaper, titled "Do not scare children of marriage" blamed mothers who regretted getting married for single individuals who were avoiding marriage. That article put forth that mothers scared their children at the age of marriage by saying "Nothing changed after I married," and "You will see when you get married". While it was emphasized that the most valuable gain of the parent is having children, it was specified that "Marriage not only is beneficial for both themselves and for their families but also affects the society and morality" (3 February 1930). Although male-female relationships were encouraged in the public sphere, to prevent the relationships not approved by society and raise future generations, marriage was emphasized as the only way.

In 1931, Akşam newspaper conducted a survey on "Why the marriage is declined?" and inquired about marriage and the changing social roles of women by asking some of the republic elites. During the month long survey, it is interesting that in the message of pioneer women domestic duties and maternity role of the women were highlighted. For example, Halide Nusret, an author advocating old social values, indicated, "If the women work like their men, the men can't find the joy and the rest at home. Because when the women work they become nervous. In my opinion women shall stay at home, raise their children. Nobody raises a child like an endearing mother" (16 February 1931). Academician Orhan Saadettin, a male surveyee, overstepped the boundaries by saying that the education should be different for girls and boys. According to Orhan Saadettin, every girl is a candidate to become a mother and for this reason, future's mothers should be disciplined properly ( 8 March 
1931).

In the social construction of the Kemalist ideology, family was considered as the base of the generation who are patriotic and committed to the Republic values. While family was exalted as an institute which assured the social order and constituted social relationships, the task of transferring national values throughout the generations was given specifically to the women. In a caricature, titled "Ideas by drawings: Protecting the family unit" on Vakit, an important newspaper relating regime's values and reforms to the public, display the importance of home and family, and the concern about social changes. In this caricature, it was expressed that while the family institution losing power and the public prosperity and benefits replacing the individual prosperity and benefits, the family had initially to be protected since it was the base of social life (11 February 1931).

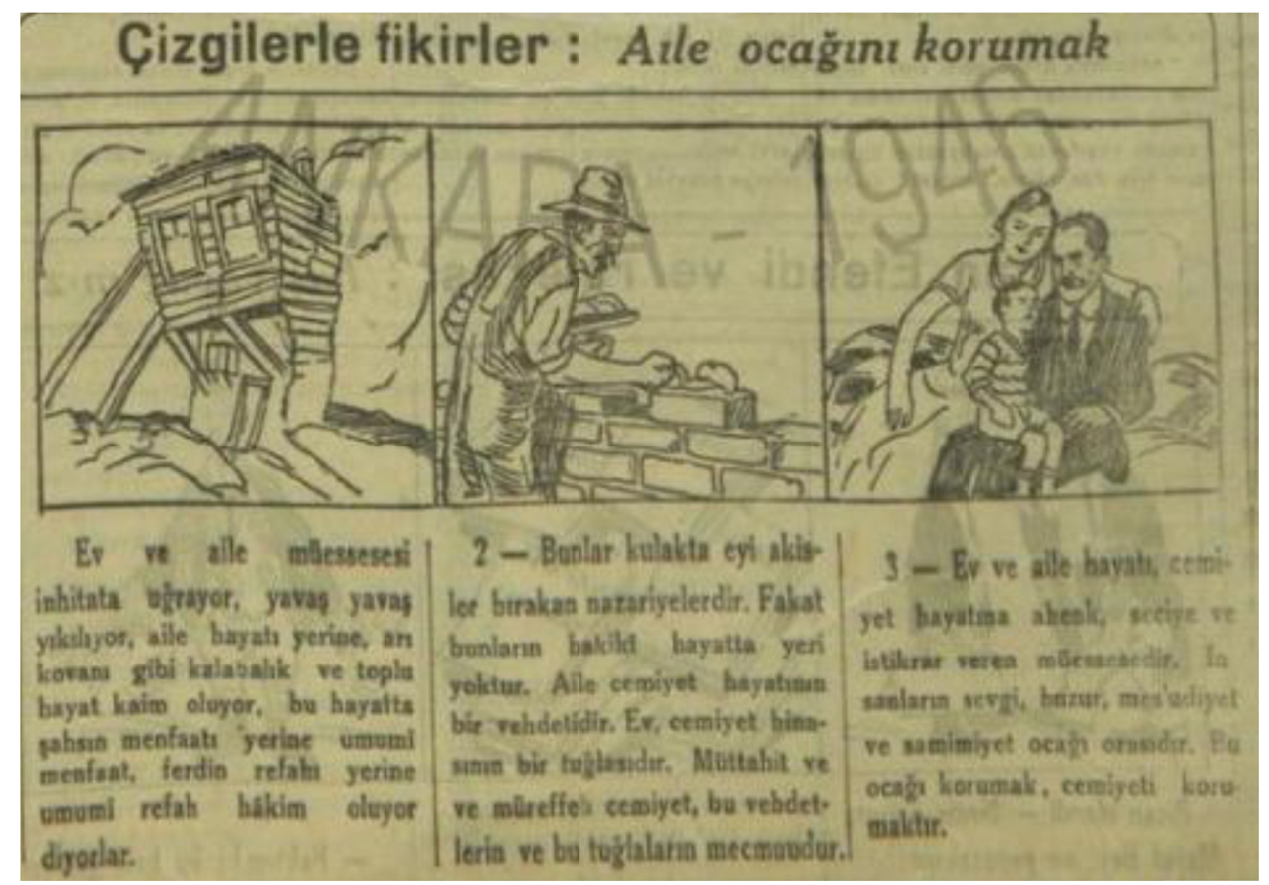

Figure 2. Ideas by drawings: Protecting the family unit

On columns of newspapers, it was egregious that some male authors expressed their concerns about the domestic roles of women and maternity. On these articles, women who wished to work were blamed for damaging not only their family but also the society. In an article, written by Peyami Safa, a famous writer of Early Republic Era, while the concern about working women and their families was indicated, it was expressed that "We should ban Turkish women from work which keep women away from maternity" (Cumhuriyet, 22 August 1936).

In the Early Republic Era, education policies on increasing educational opportunities for the girls gathered pace. On the other hand, extensiveness of vocational schools, based on the maternity and the domestic duties of the idealized women, called attention to İsmet Paşa Kız Enstitüsü, which was one of the examples of vocational schools. This institute was evaluated as an education institute which gave vocational training on domesticity and the childcare, and generated women who were desirable housewives, conscious childcarers, talented handcrafters and skillful cooks. The goal of the courses on childcare was described as: "These courses include mother and child welfare. Holding a child, giving the child a bath, breast feeding, sterilizing nursing bottles, dressing the child and so on. At the same time, the students were taught to weigh babies to evaluate their health. It was hoped that the students who attended those courses would be perfect mothers who raise robust and healthy children" (Hakimiyet-i Milliye, 24 January 1930).

As seen in the example, in the Early Republic era Newspapers, from the ideological aspect while women were shown with motherhood and domesticity roles, presentation of children on newspapers were robust, healthy, well-cared, patriotic, respectful and good individuals.

When referring to the issues and messages on the newspapers that analyzed for the study, it can be summed up that new regime required from the women to raise psychologically and physically healthy, patriotic, committed to national values, honest, industrious children. In the contents about the women, maternity roles were 
emphasized and how to be a good mother was articulated. The idealized mother figure should be conscious, endearing and at the same time disciplined; be best friend to her children, care about their health and train them to be well-mannered individuals. In the newspapers famous women of the era and the experts published articles on subjects such as child welfare, feeding, childcare, child training with titles such as 'motherhood guide and advice for mothers'. (Vakit, 27 April 1930).

As much as the responsibility encumbered on mothers about child training the advice was also rigid. If a child is not well mannered it is considered that the mother doesn't train her child properly. An article indicated that affection and respecting children's freedom and self-esteem are needed for psychological development of them. It includes rigid accusations such as "If mothers are extreme on affection, tight on freedom, inattentive on self-esteem, they are the biggest enemy of their children" (Cumhuriyet, 9 March 1930).

An article, written by Peyami Safa, on Cumhuriyet newspaper, entitled "Turkish children must live" had similar perspective. In the article, a book which is written by Dr. Besim Ömer Akalın with the same title, in which the subject of raising healthy children and avoiding child death was mentioned, increasing the consciousness of the women was shown as the key factor. Safa advised that this book was to be read at every girl-school. Safa blamed only the mother for child's death by saying, "Every Turkish women should read and memorize this book in order not to allow the grim reaper to engulf our children." (19 September 1936).

The women's responsibility of raising healthy children was emphasized via news, articles, caricatures and advertisements. It was shown that one of the main conditions for being healthy was being well nourished. In a syrup advertisement, reflecting this perspective, mothers were warned about considering their children's health. A syrup named "Arsenoferratose", advertised with the title "A Good Mother" and continued by saying "A mother who worried about her child's health, realizing her child weakened due to any sickness should give her child who had anemia and had no appetite". Another advertisement, prepared with the same perspective, was a baby powder adds. The context of the advertisement included, "A fortunate mother achieved her baby's skin delicacy by the help of 'Pertev Baby Powder" and the advertisement figure showed the 'fortunate mother' embracing her baby.

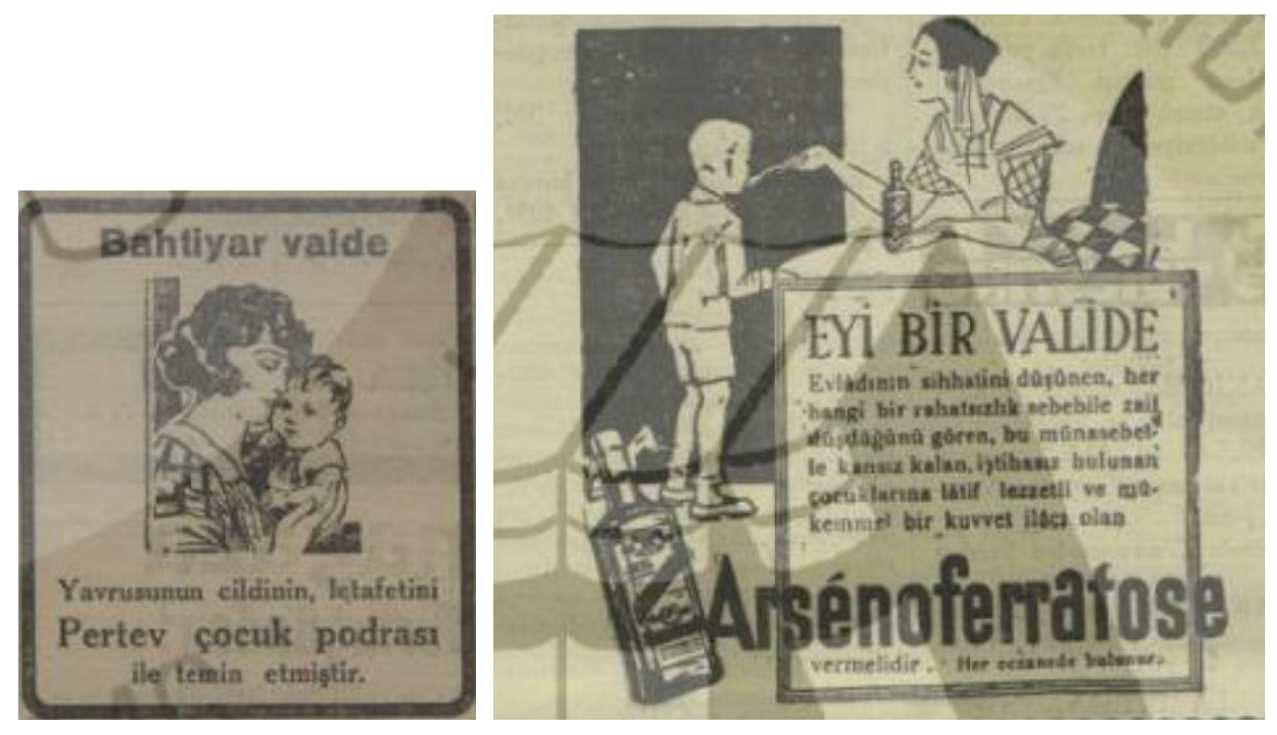

Figure 3-4. A good mother /A happy mother 


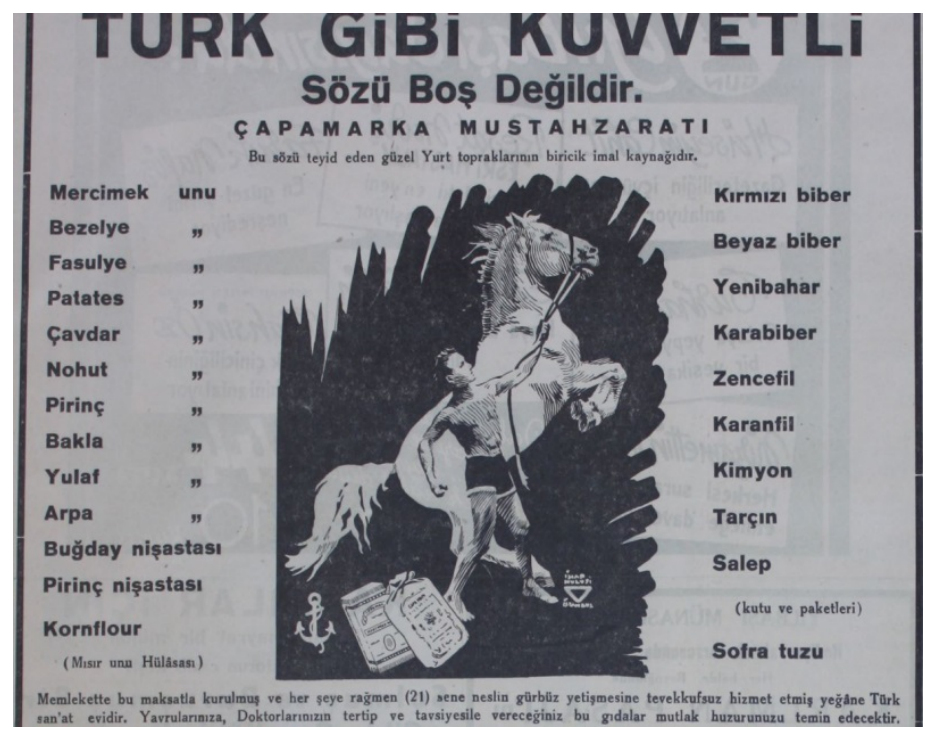

Figure 5. Strong as a Turk

While in the advertisement it was claimed that some legumes and spices would make future generations robust and healthy, this claim was highlighted in the motto "strong as a Turk". In general, beautiful and robust children were used in these kinds of advertisements. During that era one of the most used advertisements, "Hasan's Dense Flour" used lovely babies and claimed that babies being fed with flour of legume, vegetables and grain would be happy, healthy, chubby and vigorous.

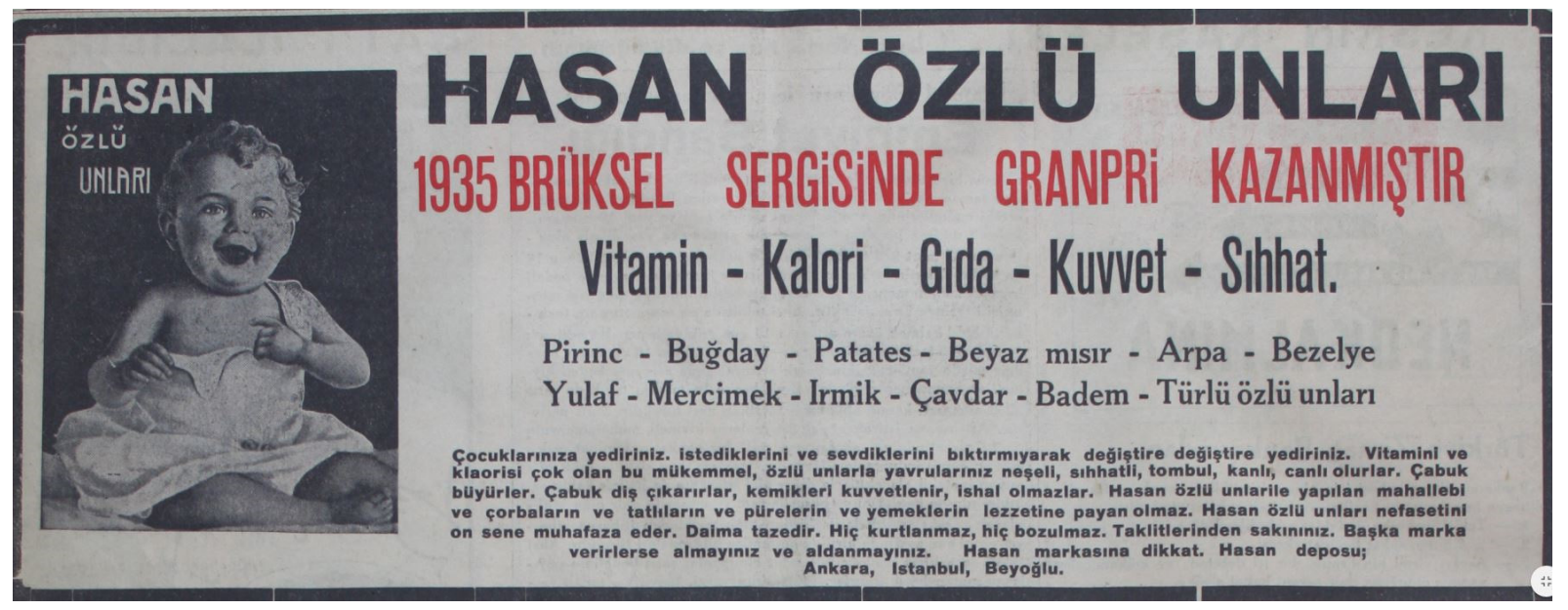

Figure 6. Hasan's Dense Flour (Note 7)

Long war years wearing the young population down in Turkey was the main reason of caring about the children and the young, and the desire of raising a healthy generation. Furthermore in time of economic crisis nourishment opportunities of the public was inadequate. On the newspapers, while having robust children were exalted as a mother's success, mothers were advised to do their best. To reach these goals, in the 1920s and 1930s Robust Child Contests were organized by the Turkish press and civil and public institutions. Such contests, which might be counted as activities to constitute the social awareness about childcare and child welfare, were open to the public and promoted raising healthy children.

These contests became traditional after the contest of Himaye-i Etfal Society held in 1926. This contest, the first of its kind, was announced with the second issue of Robust Turkish Children Magazine, which played an important role as an external house organ of Himaye-i Etfal Society. Himaye-i Etfal Society, contributing to the aim of the regime with both economic means and awareness raising activities, published Robust Turkish Child 
Magazine between 1926 and 1935. Himaye-i Etfal Society defined the contest as a national mission to decrease infant death rate and to raise robust children, used Robust Turkish Child Magazine to replace some incorrect information and superstitions with scientific knowledge and behaviors. (Sarkkaya, 2012: 202).

It was seen that national press supported such contests, which was aimed to encourage the families by exposing robust and lovely children photographs on the pages. Akşam newspaper was a pioneer on the subject within national press. A series of advertisement, titled "The prettiest and the most robust boy and girl" was announced that every boy and girl between 7 and 12 years old could apply the contest by having their photo taken with no cost in 'Photo Shop Sureyya'. Some of the most important conditions to be able to join the contest were not having chronic illness and not being obese. After end of application term the readers were requested to choose among the candidates photographs submitted on the newspaper. The boy and girl candidates would be chosen as the loveliest and the most robust child in İstanbul and their families would be awarded with 25 Turkish liras. Furthermore, it was announced that the rest of the first five would have got some presents. Every day on the first page, one of the candidate's photographs was published and the readers were asked to cut out the coupon underneath the photograph (19 June 1931).

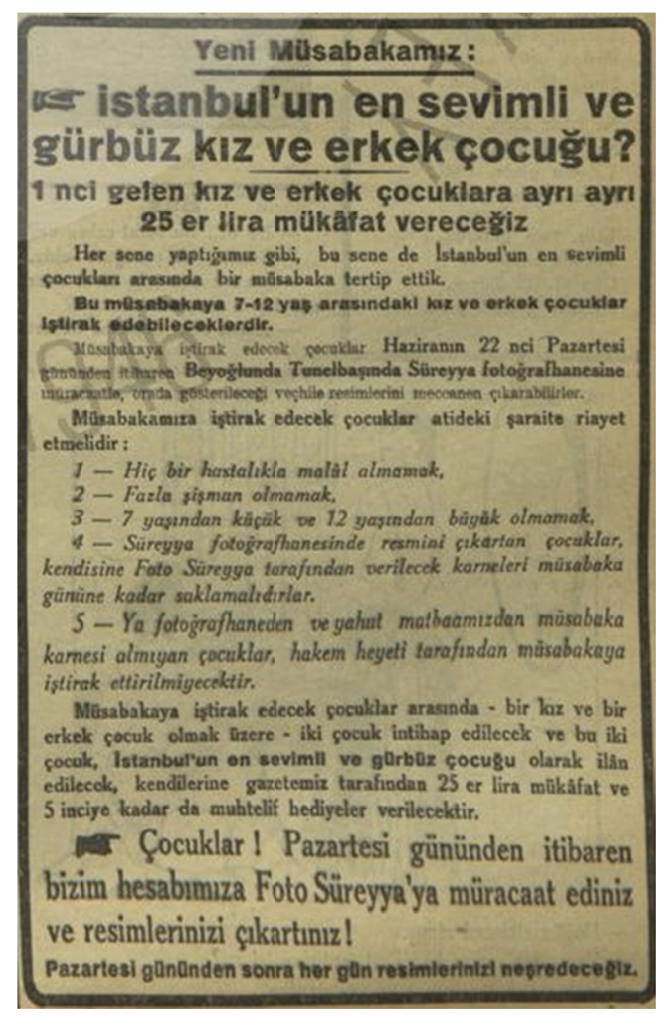

Figure 7. The Advertisement about the Robust Children Contest

Another institute holding such a contest was Kizllay. In 1936, Kizılay held the contest as a part of the Kermis. During the Kermis, a jury composed of prominent doctors of Istanbul first examined the children in order to join the contest and then the ballot started (Cumhuriyet, 10 August 1936). When the photo taken from the contest was observed, it was significant that most of the contesters were flabby. The dominant image of healthy children in the era was the vigorous and the plump. It was thought that a skinny and pale child was sick. In addition to this, the obese ones were not preferred, either. Encouraging physical training and activities from the early age were other indication of the desire to raising healthy generation. 


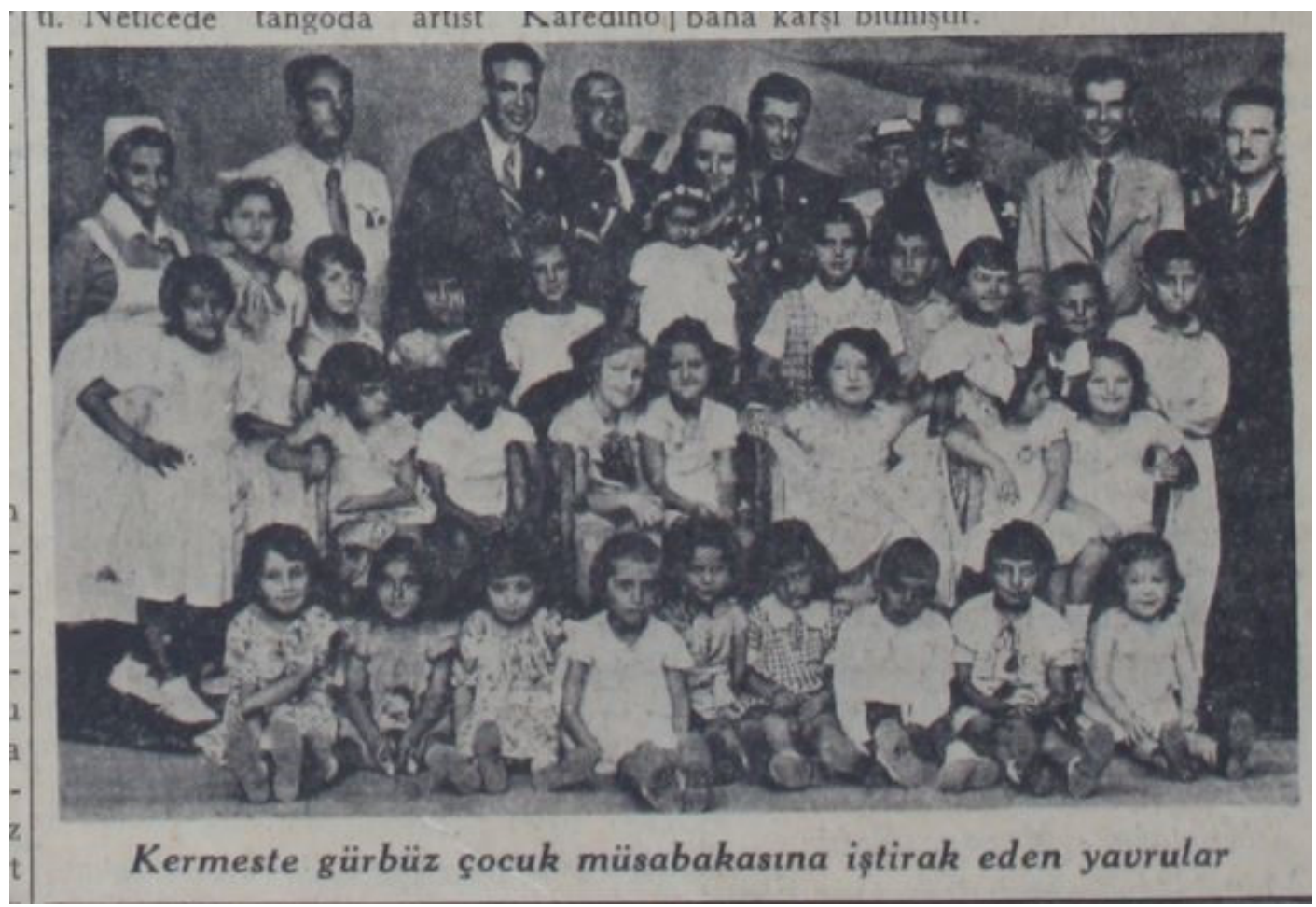

Figure 8. Robust Children Contest

The requirement of well-trained young population, seen as the way to guarantee the future of the nation, was highlighted on Hakimiyet-i Milliye newspaper, the voice of the government. In articles written for 23rd of April, National Sovereignty and Children Day, the importance of raising well mannered, patriotic, healthy children was emphasized. In one of these articles, Kazım Nami, advocated the idea that "children belong to the state". It insisted on training coherent with the state schools and the goals of the state took precedence the goal of the families (Hâkimiyet-i Milliye, 23 April 1932). Another article on the same page written by İzzet Ulvi, member of the parliament, stated, "Lots of children mean excellent children". He thought that having a lot of children was a national duty and repeated the saying, "Each more people is a hope more." İzzet Ulvi indicated that while there was no problem with birth rate, it was immensely difficult to raise them healthily. He also highlighted the requirement of "physically and psychologically strong children" (Hâkimiyet-i Milliye, 23 April 1932). 


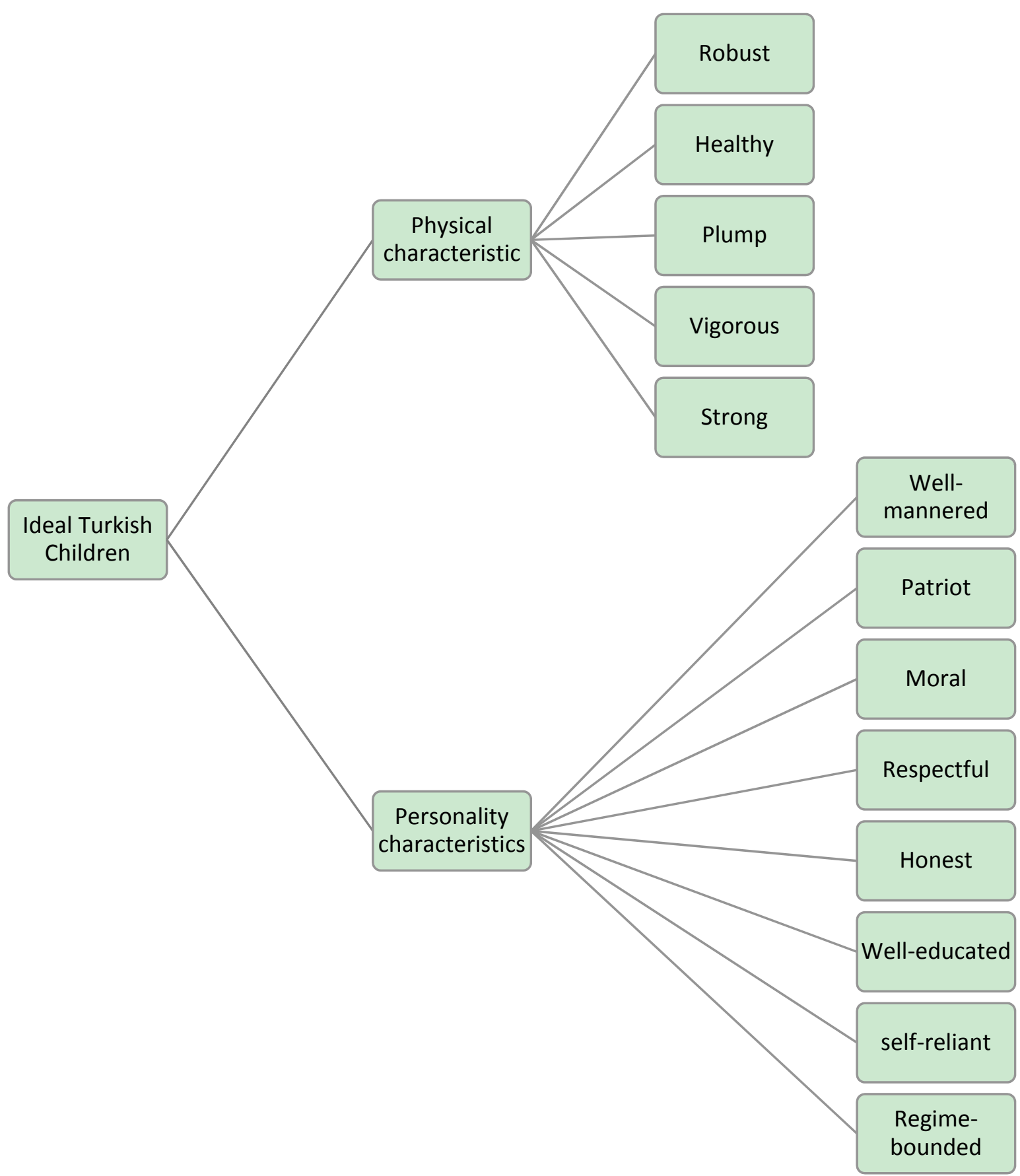

Figure 9. Ideal Turkish children terms used in the studied newspapers

Furthermore, doctors' advice appeared in the newspapers. It was understood that some ideas put forward the maternity role of the women. For Example, Dr. Kadri Raşit Pasha stated, "Our women should be a housewife and a mother." In addition Dr. Kadri Raşit Pasha was concerned about health of the new generation and insisted on his stated ideas. He said that unlike the saying stated "Strong as a Turk", the new generation was weak, peal and skinny, and added "I would rather a well-raised future nation than our women's gossip and demands. I am stating those ideas as a thirty-year-experienced-doctor. The ones who raise the generation strong are breastfeeding women who think of their children but nothing else. What women think does not matter!" (Cumhuriyet, 23 April 1930).

In 1930s another national population policy was to support families economically with many children. The Hifzissihha Act came into force in 1931, enabled fund a medal reward given to the families with the six and 
more children. The governorate located the families with many children and reported the name of the families and number of their children to the Ministry of Health ( Hakimiyet-i Milliye, 21 January 1931). In the first place, it was reported that number of families with many children from 19 provinces was more than 13 thousand. It was observed that Hakimiyet-i Milliye and Akşam newspapers published the photographs of the some families with many children to publicize (Akşam, 18 January 1931).

In the 1930s, when the meaning of families was paramount, while government stimulated the population growth, the ambition of rising healthy and strong generation by women was in the forefront.

\section{Conclusion}

Akşam, Cumhuriyet, Hakimiyet-i Milliye/Ulus and Vakit/Kurun were examined based on the depiction of the children in the early Turkish Republican newspapers, emphasis of ideology in these newspapers and the question of consistency in that the newspapers handle the new generation at descriptive level?

A total of 191 contents have been reached among which 6 contents are categorized as advertisement text, 38 as news, 14 as cartoon and 133 as corner writing/article. As seen Figure-9, the children of the Republic should have well-mannered, patriot, moral, respectful, honest, well-educated, self-reliant, and regime-bounded as personal characteristic; robust, healthy, plump, vigorous, and strong as physical characteristic. Founding Fathers focused on the health policies for child welfare since they believed that aforementioned generation was a guarantee of the newly funded regime. In order to achieve the duty of a raising healthy generation, the Republic struggled against fatal epidemics around the country, established pediatric services, provided medical supply to women during pregnancy and postpartum period, endeavored to minimize infant and child death rate. In this period, Turkish women were defined as having maternity roles and given the responsibility of rising healthy children. To realize this ideal, educational activities appeared in public sphere. Turkish press of the era outshined as an ideological tool by putting policy of the healthy and robust children into circulation. The press introduced the expectations, the desired aspects and the changes about the idealized Turkish children within the framework of new regime's modernization perspective. In some expressions shown on the newspapers, it was highlighted that the principal role of women was maternity. In the social construction of Kemalist ideology, family was considered as the base of the generation who are patriotic and committed to the Republic values. There appeared the didactic articles on child welfare, effective child communication with the others, and childcare. The task of transferring national values throughout the generations was given specifically to the women. Education policies on increasing educational opportunities for the girls gathered pace but extensiveness of vocational schools, based on the maternity and the domestic duties of the idealized women, called attention. The women's responsibility of raising healthy children was emphasized via news, articles, caricatures and advertisements. On the newspapers, while having robust children were exalted as a mother's success encouraging physical training and activities from the early age were other indication of the desire to produce a healthy generation. It is clearly seen that the contents of the analyzed newspapers are harmonized with the Republic's child ideology. It can be said that the newspapers' mission of adopting new regime's values and reforms are the same for the child ideology.

It can be said that the dominant ideology of the early Turkish Republic and its principles had a great impact on the representation of the children in the newspapers that imposed nationalistic values on Turkish families. This ideology acted prescribing what ought to be and ought to be thought. Therefore, a critical approach towards this set of ideas can help understand the nature of ideologies in Turkish society. Thus, the emergence and recognition of children as independent individuals in the early Turkish Republic do not presuppose the fact that those children and their families were free in that they could constitute their selves, their personal histories and cultural values. They were raised and conditioned under the influence of certain elites that proposed nationalistic and republican values and ideas. This historically ideological background stills penetrates and frames contemporary Turkey's political, social and cultural agenda.

\section{References}

“Altıdan fazla çocuğu olanlara", Hakimiyet-i Milliye, 21 January 1931, p.1.

"Annelere Tavsiyeler", Vakit, 27 April 1930, p.5.

“Çizgilerle Fikirler:Aile Ocağını Korumak”, Vakit, 11 February 1931, p.3.

“Çocuğun En Büyük Düşmanı Annesidir”, Cumhuriyet, 9 March 1930, p. 5.

“Çocuklarımızı izdivaçtan ürkütmeyelim”, Akşam, 3 February 1930, p.5.

"Çok cocuklu aileler”, Akşam, 18 January 1931, p.5.

"En güzel ve gürbüz kız ve erkek çocuğu”, Akşam, 19 June 1931, p.1. 
“Evlilikler Neden Azalıyor?”, Akşam, 16 February 1931, p.1,2.

“Evlilikler Neden Azalıyor?”, Akşam, 8 March 1931, p.1,2.

“Kermes Eğlenceleri”, Cumhuriyet, 10 August 1936, p. 5.

“Müstakbel Türk Kadınlığına Hitap Eden Bir Müessese: İsmet Paşa Kız Enstitüsü”, Hakimiyet-i Milliye, 24 January 1930, p.6.

Alexander, J. (2015). The major ideologies of liberalism, socialism and conservatism. Political Studies, 63(5), 980-994. https://doi.org/10.1111/1467-9248.12136

Balibar, E.(2007). Ulus Biçimi: Tarih ve İdeoloji, Metis Yayınları: İstanbul.

Duman, Ö. (2016). Gürbüz Türk Çoçuğu Projesinin Eylemsel Bir Örneği: Hereke Çocuk Kampı (1936-1939), Uluslararası Gazi Süleyman Paşa ve Kocaeli Tarihi Sempozyumu, 25-27 Mart, Kocaeli, p.2211-2217.

Durna, L. (2009). Kemalist Modernleşme ve Seçkincilik. Ankara: Dipnot Yayınları.

İzzet Ulvi, "Her fazla insan bir fazla ümittir", Hakimiyet-i Milliye, 23 April 1932, p.3.

Kadri Raşit “Kadınlarımız ev hanımı ve anne olmalıdır.”, Cumhuriyet, 23 April 1930, p.5.

Kandiyoti, D. ( 2013). Cariyeler, Bacılar, Yurttaşlar, Kimlikler ve Toplumsal Dönüşümler. İstanbul: Metis Yayinlar1.

Kazım Nami, "Çocuk Devletindir”, Hakimiyet-i Milliye, 23 April 1932, p.3.

Minar, D. M. (1961). Ideology and political behavior. Midwest Journal of Political Science, 5(4), 317-331. https://doi.org/10.2307/2108991

Mullins, W. A. (1972). On The Concept of Ideology in Political Science. American Political Science Review, 66(2), 498-510. https://doi.org/10.2307/1957794

Okay, C. (1998). Osmanlı Çocuk Hayatında Yenileşmeler: 1850-1900, Kırkambar, İstanbul.

Oktay, E. Y. ( 2013). Türkiye'de Cumhuriyet'in İlanından Günümüze Uygulanan Nüfus Politikaları. Yalova Sosyal Bilimler Dergisi, 7, 36.

Onur, B. (2005). Türkiye'de Çocukluğun Tarihi. İmge Yayınevi: Ankara.

Öztan, G. (2009). Türkiye'de Çocukluğun Politik İnşası. Basılmamış Doktora Tezi, Sosyal Bilimler Enstitüsü, İstanbul Üniversitesi, İstanbul.

Peyami Safa, "İş ve Ev", Cumhuriyet, 22 August 1930, p.3.

Peyami Safa, "Türk çocuğu yaşamalıdır”, Cumhuriyet, 19 September 1936, p.3.

Sancar, S. (2013). Türk Modernleşmesinin Cinsiyeti. Ankara: İletişim Yayınları.

Sarıkaya, M. (2012). Gürbüz Çocuk Yarışmaları. Atatürk Üniversitesi Atatürk İlkeleri ve İnkılap Tarihi Enstitüsü Atatürk Dergisi, Vol: 1, p. 203.

Şirin, F. S. (2013). İktidar ve Çocuk. Electronic Turkish Studies, 8(8), Ankara.

Şirin, M. R. (1999). Modern Çocukluk Paradigması, Kadınlar ve Çocuklar, Düşünen Siyaset, 5, Ankara.

Tekeli, İ. (1990). Osmanlı İmparatorluğundan Günümüze Nüfusun Zorunlu Yer Değiştirmesi ve İskan Sorunu, Toplum ve Bilim, Vol: 50, p. 49-71.

Toprak, Z. (2015). Türkiye'de Kadın Özgürlüğü ve Feminizm (1908-1935). İstanbul: Tarih Vakfı Yurt Yayınları. Üstel, F. (2005). Makbul Vatandaş'ın Peşinde: II. Meşrutiyet'ten Bugüne Vatandaşlık Eğitimi, İletişim, İstanbul.

Žižek, S. (1989). The sublime object of ideology. London: Verso.

\section{Notes}

Note 1. In the scope of this study, the owners of the analyzed four newspapers were, at the same time, the editor-in-chiefs of the newspapers. Furthermore, in the analyzed era, the most of the owners and columnist of the newspapers were, also, politicians, diplomats, and bureaucrats. Because of their positions, they sincerely advocated the republic ideology as well as ideology about the children.

Note 2. Robust Children: Healthy, strong, plump and well-nourished children. 
Note 3. Father: Although the father during the Ottoman society represents the values such as hierarchy, rigidity, and absolute sovereignty in the family, the new men of the republic is considered as being more flexible, having emotional bond with their spouse and children, being more independent from their family elders, and being head of their nuclear families. In the scope of creating image of the citizen and the modern father/modern husband of the Turkish nationalism, while defining the paternity role of the modern republic men, the strict and despotic fathers replaced by tender ones. But, the documents, such as memoirs of the era, indicated that fathers could not develop close relationship with their children (for detailed information Kandiyoti, D. ( 2013). Cariyeler, Bacilar, Yurttaşlar, Kimlikler ve Toplumsal Dönüşümler. İstanbul: Metis Yayınları). Furthermore, the responsibilities encumbered over the mother was in the foreground in the child raising policies of the Republic ideology. The numeric data of the studied newspapers soundly indicates that the use of the term of father/fatherhood was well behind the use of the term mother/motherhood.

Note 4. Mothers' lap: The affectionate, kind and compassionate surrounding of the mother.

Note 5. The term refers to years between 1923 and 1938 within the scope of this study.

Note 6. Himaye-i Etfal Society, at first a local society, was found in 1908 in Kirklareli to protect and safeguard the gamin, who lose their parent during the war. In 1921, It was reformed by the request of Atatürk, after 1921, waif urchin, was also protected and provided health service, fund and food; destitute families were given maternity benefit and delivered milk and the children of those families were helped to continue their education.

Note 7. Akşam, Vakit/Kurun, Cumhuriyet, Hakimiyet-i Milliye/Ulus analyzed newspapers between 1930-1938, all figures from 1 to 5 were published during the time in various issues of on these newspapers.

\section{Copyrights}

Copyright for this article is retained by the author(s), with first publication rights granted to the journal.

This is an open-access article distributed under the terms and conditions of the Creative Commons Attribution license (http://creativecommons.org/licenses/by/4.0/). 